\title{
Automação de microscópio para experimentação remota no ensino da Biologia
}

\section{Janneffer K. Costa Silva*, Eduardo Galembeck}

\section{Resumo}

Tendo em vista a viabilidade de um microscópio para experimentação remota, que foi desenvolvido a partir de sistemas embarcados para vincular um microscópio real à internet sendo possível manipulá-lo através do aplicativo/site do LTE (Laboratório de Tecnologia Educacional). O foco do projeto é otimizar esse sistema para uma experiência cada vez mais confortável e intuitiva ao usuário.

\section{Palavras-chave:}

Microscopia, Experimentação, Sistemas Embarcados.

\section{Introdução}

Sistemas embarcados estão protagonizando muitos projetos em diversas áreas atualmente. Isso deve-se ao fato de que é um sistema relativamente simples onde é possível programar e executar os comandos programados com o auxílio de periféricos como motores, módulo de internet e etc.

No início do projeto a placa Arduino foi a base de todo o desenvolvimento do projeto e contém toda a programação envolvendo os motores e a conexão com a internet. A utilização de suportes para os motores fez necessário o uso de impressora 3D onde as peças eram produzidas.

O sistema possui dois motores e funciona da seguinte forma: um deles está relacionado ao eixo x, e o outro ao eixo y, possui um led que faz a iluminação da lâmina, um joystick para controle manual, um módulo para conexão com a internet, e duas câmeras para transmitir as imagens em tempo real ao site. A movimentação sobre a platina do microscópio funciona através um sistema de coordenadas que são enviadas pelo site do LTE pelos usuários que também têm o controle sobre a iluminação. Uma fila possibilita a utilização de um usuário de cada vez.

\section{Resultados e Discussão}

Ao término do primeiro modelo de microscópio foi notada algumas características que dificultavam a utilização do usuários. Uma em especial que foi observada foi a dificuldade dos usuários em relação a encontrar o objeto da lâmina uma vez que até então os motores varriam toda a área da platina. Esse problema foi sanado com a implementação de um controle manual, onde o objeto é setado manualmente, e uma delimitação da área onde é possível navegar somente sobre o objeto da lâmina.

Após colocar em prática esse novo recurso, foi possível perceber uma precisão muito pequena em relação às coordenadas de onde fica o objeto. Com isso surgiu a idéia de retirar o sistema de coordenadas de vista do usuário, e deixar apenas visível ao administrador, pois é necessário ter alguma referência para retornar à posição inicial. Os usuários veriam apenas as direções, como direita e esquerda.

Outra idéia que vem sendo estudada é a implementação do autofoco.

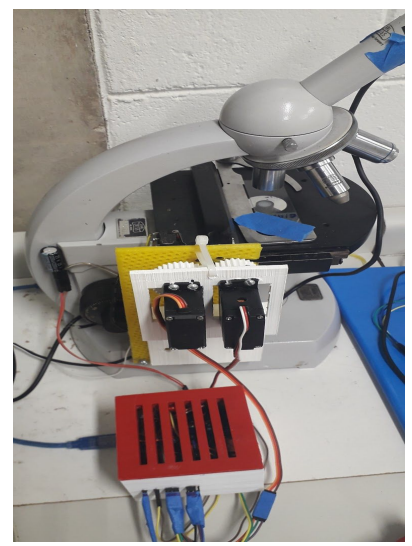

Figura 1. Microscópio.

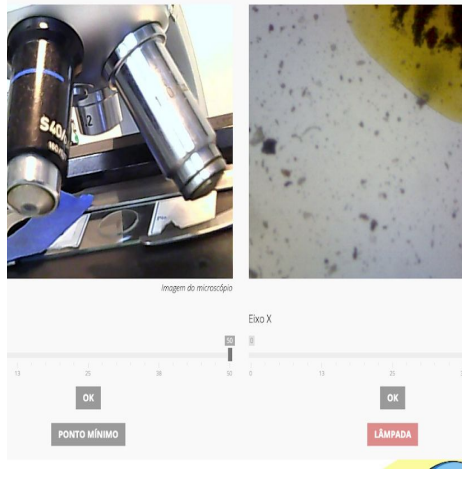

Figura 2. Interface no site.

\section{Conclusões}

Os resultados são positivos uma vez que mais pessoas conseguem ter acesso a essa experimentação já que não é muito simples ser obtida pela comunidade no geral.

O feedback por parte dos usuários ajuda muito a estudar formas de otimizar o sistema.

A possibilidade de autofoco, de forma que o objeto se ajuste automaticamente à câmera, vem sendo estudada para implementações futuras.

\section{Agradecimentos}

Agradeço ao CNPq pelo auxílio financeiro e também à FAPESP (proc. n. 16/05243-7) e ao CAPES pelo suporte ao Laboratório de Tecnologia Educacional, onde o projeto foi desenvolvido. INCT/Inomat.

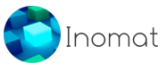

